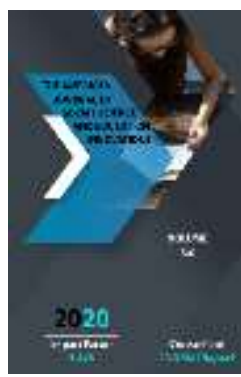

\title{
Adoption Of The Election Code Is A New Stage In The Development Of The Election Legislation Of Uzbekistan
}

\section{Kholikulov Pirnafas}

Associate Professor, Department Of Story Of Uzbekistan, Karshi Engineering And Economics Institute, Uzbekistan

\section{Journal Website:}

http://usajournalshub.c om/index,php/tajssei

\section{Copyright: Original} content from this work may be used under the terms of the creative commons attributes 4.0 licence.

\section{ABSTRACT}

The article discusses in detail the issues of developing a unified Electoral Code in Uzbekistan, which takes into account the proposals of international organizations and experts.

\section{KEYWORDS}

Democracy, elections, political system, electoral system, political institution, electoral code, electoral legislation.

\section{INTRODUCTION}

As a result of elections, the masses of the people participate in the administration of state power. Elections are a product of the centuries-old historical development of human society and represent a political institution that arose to form improved models of the state and society on a democratic basis.

At present, in many countries of the world, democratic elections associated with the formation of public authorities have become an integral part of the political system. Today, the level of development of the rule of law and civil society in democratic states is determined by the elections held in them, the participation of the population in elections, and the level of the electorate. The exercise of the right to free suffrage is determined by the will of the people and the legitimacy of any government, as well as the degree to which each person participates in the administration of his state. 


\section{MATERIALS AND METHODS}

Chapter XXIII of article 117 of the Constitution of the Republic of Uzbekistan is called the Electoral System, which strengthens the constitutional and legal basis of elections [1]. On the basis of the legal norms on elections established by the Constitution, during the years of independence, 5 laws on elections and a number of legal acts were adopted. The elections were held in accordance with the norms established by the Constitution, electoral legislation and legal documents, based on openness, transparency and national and international norms. Although the work appeared to be regulated at first glance, the huge number of legislative acts regulating elections, as well as their overlapping norms, made it difficult to organize and conduct elections.

President Shavkat Mirziyoyev in his Address to the Oliy Majlis on December 22, 2017, paid special attention to this issue: "I would also like to dwell on the electoral legislation, which is important in our political life. The six laws and a number of legal documents adopted on this occasion, unfortunately, have not yet been consolidated into a single document. Therefore, it is necessary to develop and adopt a unified Electoral Code that meets international norms and standards. It is also necessary to start developing a program of measures to prepare for the 2019 elections to representative bodies. The program should pay special attention to the introduction of new progressive practices that will ensure a more transparent political process "[2].

To ensure the implementation of the Strategy of Action for the Development of Uzbekistan for 2017-2021 and further improve the electoral legislation in accordance with the tasks set by the President, a working group has been created under the leadership of the Chairman of the Central Election Commission of the Republic of Uzbekistan Mirzoulugbek Abdusalomov. It included members of the
Central Election Commission, chambers of the Oliy Majlis, the Ministry of Justice, representatives of political parties and other public organizations, scientists, politicians and experts. The working group considered the national experience accumulated in the field of electoral law and practice in our country during the years of independence, the electoral legislation of the leading countries of the world and the United Nations Universal Declaration of Human Rights, the International Covenant on Civil and Political Rights, the OSCE Humanitarian Criteria. Copenhagen Council documents 1990, the Inter-Parliamentary Union Declaration on Fair Elections, International standards and norms for elections, as set out in documents such as the Commonwealth of Independent States (CIS) Declaration on Democratic Elections, have been constantly revised and their progressive ideas and norms were included in the draft Electoral Code [3].

The working group "studied the experience of more than 50 countries in the development of a new Electoral Code, recommendations of international organizations, including the OSCE Office for Democratic Institutions and Human Rights, SCO, CIS, World Association of Electoral Bodies, Organization of Islamic Cooperation, Recommendations of the Venice Commission were taken into account" [4].

The draft Electoral Code developed by the working group was submitted for public discussion in several directions in accordance with the Plan of Practical Actions prepared jointly by the chambers of the Oliy Majlis and the Central Election Commission [5]. According to him, the draft Election Code has been submitted for public discussion on the portal for discussing draft regulatory legal acts of the Republic of Uzbekistan (www.regulation.gov.uz) and posted on the official website of the Central Election Commission (www.elektions.uz). 
The project was widely discussed in the media

- radio, television, newspapers and magazines, on the Internet - by voters, scientists, MPs, experts, political party activists and journalists.

The project has passed a public examination by experts from civil society institutions. The draft Electoral Code was hotly debated in regional, district and city election commissions, as well as in makhallas, trade unions and educational institutions with the participation of the general public in order to obtain the views of practitioners. In particular, a round table organized on the draft Election Code in the Council of People's Deputies of the city of Almalyk, Tashkent region, a discussion organized by the Central Election Commission in Bukhara on November 16-17, 2018 in cooperation with the OSCE Coordinator in Uzbekistan and the Regional Office of the Konrad Adenauer Foundation for Central Asia, the conference "Improvement of electoral legislation and democratic elections: the experience of Uzbekistan and international practice", discussions at gatherings of residents of the makhallas "Kyzylkum", "Oktom", "Kulba" of Forish region became a platform for effective discussions. During the discussions, election experts, representatives of the population expressed their views on how to ensure fair and more effective elections.

More than 30 thousand people took part in about 300 events to discuss the draft Electoral Code, during which more than 450 proposals were received. It should be noted that the proposals include the specifics of elections to regional, district and city Councils of People's Deputies, the activities of election commissions holding elections to local councils, the number of candidates for deputies and their proxies, the registration procedure, the status of observers and plenipotentiary representatives of political parties and related transmission processes.
The hotly debated Electoral Code was adopted by the Law of the Republic of Uzbekistan "On the Electoral Code" № LRU544 on June 25, 2019 [7]. The adoption of the Electoral Code raised the electoral legislation of the Republic of Uzbekistan to a new level and, in turn, established new norms in the electoral legislation of the republic that meet international standards. They are as follows:

- The Electoral Code establishes the procedure for compiling a single electronic voter list at the legislative level (article 28 of the Electoral Code). The unified electronic voter list is a state information resource containing information on the addresses of citizens, their permanent and temporary residence in accordance with the databases of the competent state bodies. It is formed and updated on the basis of information provided by state bodies, and during the election campaign is determined by the relevant precinct election commissions.

- It has been established that no more than half of the members of a precinct election commission can be recommended by one organization (article 25 of the Electoral Code). According to previous electoral practice, most of the members of precinct election commissions were formed from one organization. In order to ensure the effective functioning of precinct election commissions, this practice was abolished in accordance with the Electoral Code.

- Requirements for members of election commissions at all levels have been increased. According to the Electoral Code, citizens who have reached the age of 21, have secondary or higher education, as a rule, have experience in preparing and holding elections, having a good reputation 
among the population, can be members of regional, district and city election commissions, district and precinct election commissions (articles 23 and 25 of the Electoral Code).

- $\quad$ "Voting" for early voters was canceled. The code introduced a single document - a ballot paper for both early voters and voters on election day (article 57 of the Electoral Code).

- It is stipulated that the voter can put the signs " +", " $v$ " or " $x$ " in the empty square to the right of the name of the candidate for whom he is voting (article 55 of the Electoral Code). According to the previous procedure, only the use of the + sign was determined, as a result, this led to invalidation of ballots with various marks, as well as to misunderstandings in accounting for the real political will of the population.

- The procedure for nominating candidates for district (city) Kengashes of People's Deputies by local self-government bodies has been abolished, and the code provided citizens with the right to participate in elections as observers, based on the position of local selfgovernment bodies in the social and political life of the country (article 33 of the Electoral Code) [8]

- $\quad$ The voter was given the opportunity to sign in support of several candidates or parties in the process of collecting signatures by political parties. Previously, a voter could sign in support of only one political party. This created some difficulties in the process of collecting signatures from political parties (article 38 of the Electoral Code).

- The time for voting in elections is set from 08:00 to 20:00 (article 51 of the
Electoral Code). According to the previous procedure, the voting time in the elections began at 06:00. Considering that the elections to the Legislative Chamber of the Oliy Majlis of the Republic of Uzbekistan and local councils took place in the winter, it is not difficult to understand that this caused certain difficulties for members of precinct election commissions.

- A procedure has been introduced for the immediate posting of copies of the protocol of the precinct election commission on the counting of votes at the polling station for a period of at least 48 hours (article 58 of the Electoral Code). This article also provides that an authorized representative of a political party participating in the vote counting process has the right to receive a certified copy of the protocol of the precinct election commission.

- $\quad$ The procedure for electing members of the Senate of the Oliy Majlis of the Republic of Uzbekistan is established by law (Chapter 14, Articles 75-87 of the Electoral Code). Previously, elections to the Senate were regulated by the Charter of the Central Election Commission.

- A procedure has been introduced for payment of travel expenses of candidates' proxies throughout the territory of the Republic of Uzbekistan at the expense of funds allocated for the conduct of elections. Earlier, no funds were allocated for the activities of candidates' proxies (Article 43 of the Electoral Code).

- $\quad$ A procedure has been introduced for considering applications from individuals and legal entities on the organization, conduct and announcement of election results (article 101 of the Electoral Code). 
- It also provides for the application to members of the Central Election Commission of the immunity rule applicable to members of the Legislative Chamber, members of the Senate (article 13 of the Electoral Code) [9].

\section{CONCLUSION}

The Electoral Code, developed at the initiative of the President, is a document that serves the implementation of democratic principles such as openness, transparency, fairness and impartiality of elections, has a relevant content and great legal, social and political significance. The adoption of this Code, first of all, prevents duplication of legislative norms in the country's electoral system, and most importantly, the implementation of the requirements of this Code will ensure a more transparent electoral process in the country, legally guarantee the implementation of new best practices.

\section{REFERENCES}

1. The Constitution of the Republic of Uzbekistan. - T .: Uzbekistan, 2019, article 117.

2. Message from the President of the Republic of Uzbekistan Shavkat Mirziyoyev to the Oliy Majlis of the Republic of Uzbekistan, December 22, 2017 // Official website of the President of the Republic of Uzbekistan - www.preresent.uz

3. A new era of electoral reform // People's Word, July 2, 2019, www.xs.uz

4. Elections in Uzbekistan will be transparent in accordance with international requirements // People's Word, November 28, 2019, www.xs.uz

5. A new era of electoral reform // People's Word, July 2, 2019, www.xs.uz
6. A new era of electoral reform // People's Word, July 2, 2019, www.xs.uz

7. Election Code of the Republic of Uzbekistan // National database on the legislation of the Republic of Uzbekistan, 06/26/2019, No. 03/19/544 // 3337.

8. See: Electoral Code, article 33; Resolution of the Central Election Commission "On the legal status, rights and obligations of observers of citizens' self-government bodies in elections to regional, district, city Councils of People's Deputies and the procedure for preparing their documents." Source: http://www.elections.uz/uz/lists/view 1485

9. See: Election Code of the Republic of Uzbekistan. - T.: Uzbekistan, 2019. 